\title{
Study on the Civil Legal Relationship of the Third Party Logistics
}

\author{
Xie jun ${ }^{1, a}$ \\ ${ }^{1}$ Sichuan college of architectural technology,sichuan, 618000 \\ a78970922@qq.com
}

Keywords: third party logistics, logistics contract, legal relationship

\begin{abstract}
The rapid development of the third party logistics have speed up the turnover of goods efficiency and promoted the rapid development of China's economy. Aiming at the problem of the lack of relevant laws of third party logistics and the lagging jurisprudence research, the study was researched with the intersection of law and management knowledge in this paper. Taking the civil legal relationship of the third party logistics as the breakthrough point, the legal characteristics, and the third party logistics in the legal relationship between the subject and the object and the third party logistics civil legal relations was researched systematically. At last, the behavior characteristic of third party logistics and the legal nature of contracts were analyzed deeply.
\end{abstract}

\section{Introduction}

With the globalization of economic development, the revolution of information technology and the refinement of social division of labor, the third party logistics began to develop and form a new industrial chain. Third party logistics development not only promotes world economic prosperity, but also has a profound impact on the social production and the development of retail business, and has gradually developed into a pillar industry. With the continuous expansion of the connotation and extension of the third party logistics, legal issues and legal relations become increasingly complex[1]. But the third party logistics related laws and law is less, and the third party logistics market rights can not be fully protected, which seriously affected and restricted the industry's healthy development. Therefore, with the combination of law and management knowledge, taking the civil legal relationship of the third party logistics as the breakthrough point, the legal characteristics, civil legal relations and the legal relationship between the subject and the object in the third party logistics was discussed in this paper, in order to promote the establishment and perfection of the legal system of the third party logistics[2].

\section{The legal character of the third party logistics}

Logistics activities are separated from the production of economic activity in the community. Logistics activities have made the material circulation and movement between the different processing points, without changing the shape and size and nature of the material itself, but only made the time or spatial position change of state. In order to improve the efficiency of material circulation, the third party logistics industry with the deeper degree of specialization began to appear[3].

The third party logistics is defined as a business model by the outside supply side and demand side logistics enterprises to provide logistics services, and is a necessary stage of maturity adjustment and socialized production enterprise management mode of development. Based on the theory of the third party logistics, beside of distinguish of the third party to the first party (supplier), second party (goods demander), other characteristics of the third party logistics also includes the following points. Firstly, the third party logistics operator is another party, outsourcing of logistics is implemented through third party. Secondly, the mature of network technology and electronic data interchange technology is the premise and basis for implementation of the third party logistics. Thirdly, the relationship between third party logistics operators and 
goods supply enterprises is based on mutual trust and cooperation based on partnership alliance[4,5].

The legal relationship of the third party logistics was analyzed from the legal aspects in this paper. Because the time from planned economy to market economy time in our country is not long, the overall market philosophy should be perfected, the legal rules and the environment and the market existence and development is relatively more scarce, so in good faith based market order and logic is still in the process of continuous construction. Especially in the third party logistics, legal disputes between the logistics operators and logistics consumers emerge in an endless stream. In the aspect of the subject of the legal relation, the third party logistics should be multi subject, as the civil and commercial activities should be subject to civil legal regulations, the provisions of the civil law make clear the equality of the main activities in the market economy. In the third party logistics, the operators are just fully independent from the main sale or supply and demand sides of the identity, in which a party engaged in the circulation of goods services. The new legal relationship will be produced between third party logistics operators and goods suppliers or the demand of goods. The third party logistics and the "multiple subjects" effect may also provide objective as the complexity of legal relations, and indicate the necessity for the development of related research.

In the object of legal relationship, the object of the legal relationship in the third party logistics is a behavior. The law is just to adjust the social relationship through adjusting the interpersonal behavior to the people, and the law is the fulcrum of behavior. In the third party logistics activities, all behaviors related to logistics service are concerned by law. In the market process, these behaviors usually include warehousing, storage, transport, handling, assembly and so on, which is closely related to the common features of logistics. As the behavior of the original analysis of the logistics concept, they do not produce or create real, and only complete the specific flow and displacement of the real in time or space.

Objective characteristic of third party logistics is the pursuit of profit. Analysis of the characteristics of third party profit purpose should be divided into two dimensions. First of all, it is the full understanding of the third party logistics enterprises to reduce the cost of production and support. Secondly, it is the full understanding of the third party logistics for profit itself and in its activities influence. In addition to for-profit, for-profit emphasizes not only the limited needs of the logistics consumers, but also from the operation of the third party logistics demand of people. In the framework of the contract within the scope of the operation of the third party logistics, people accept the specific business engaged in the circulation of goods and realize its own profit.

In the aspects of the property of the third party logistics, it is ought to be legal action based on the contract orientation. The legal analysis according to the third party logistics should be based on the contract framework, although tort disputes are also included in the third party logistics activities, but the most basic legal relationship is established by contract.

\section{The subject and object of legal relationship of third party logistics}

\section{A.The legal status of third party logistics subject.}

First of all, from the perspective of the third party logistics civil legal relationship, if they are regarded as the principal - agent relationship, the existence of client is the premise of the legal relationship. Supply side and demand side of goods is a prerequisite for third party logistics legal relationship, with the loss of a relationship between supply and demand in this market, the third party logistics is not possible existing. In practice, the principal-agent relationship among principal often from the goods supplier or demander, if the goods suppliers entrust the third party logistics operators to engage in goods circulation behavior, then it is the principal, buyer who receive the goods will be the opposite party, and vice versa. 
Secondly, in the relative relationship of principal-agent, the operation of the third party logistics is the goods supply agent. In practice, because of the complex relationship between logistics and frequent market risk and market profit driven and risk aversion based on instinct, third party logistics business often appear many complex issues, it is not clear that the risks and responsibilities should be borne by the principal or agent. Whether the third party logistics behavior way how complex, its subject status in the third party logistics civil legal relationship, the goods circulation behavior with respect to goods supply and demand relationship still play the role of the demand and supply of goods entrusted agent.

Thirdly, the agent identity of third party logistics operators is not named. The third party logistics activities especially involved logistics business processes, such as reducing transaction procedures based on the need to promote business flow. Sometimes, according to the different situation, the third party logistics operation agent will choose to disclose or hide the client identity to relative party. China is a traditional civil law country, and it is not enough flexible in the design of machinery and slightly agent system, Anglo American non manifest agency system concept and provides good reference for us. According to the provisions of China's "contract law" article 402nd and article 403rd, legal representatives of third party logistics operators in non identity should governed by themselves.

\section{B.The object of civil legal relationship of the third party logistics.}

The object of legal relation is the object which is pointed by the subject of legal relationship according to legal rights and obligations. The decision based on different distinction between rights and obligations, which constitute the different legal relationship of good things. In the research object of the third party logistics of civil legal relations, the subject of legal relationship of rights and obligations of the third party logistics to do is not materialized, their positioning in the spiritual products is easy to adjust the direction of the third party logistics legal relationship tends to be more and more intellectual property rights and other intangible assets of social management system instead. According to the third party logistics activities, the representation is various. From the legal value point of view, the characteristics of the third party logistics civil law relation object includes three aspects as follows: species only, extension and complex.

Firstly, the main features of civil legal relationship object in the third party logistics is only a kind. From the legal logic perspective, the core is logistics service behavior. No matter how complicated the development of logistics activities, the object of legal relationship is only one, namely the logistics service behavior, while the benchmark analysis of third party logistics civil legal relationship is only one, namely carrying on the explanation and analysis for logistics service behavior. Therefore, the main characteristics of the third party logistics civil legal relationship, is the only one of the logistics service acting as the representative of the object types.

Secondly, the main character of the third party logistics civil legal relation object is the extension and expansion. On the other side of the third party logistics civil legal relation object type uniqueness is reflected as third party logistics activities extension of the openness and expansion. The challenge from the theory of supply chain is the development of the theory of supply chain and its profound influence in the field of logistics, which created a vigorous development of the third party logistics. Third party logistics operator began to actively participate in management and integration of supply chain, which provided more detailed and highly integrated logistics services for the third party logistics. Under the background of the only object behavior, extension of the third party logistics legal relationship of the objects constantly show characteristics of expansion, the characteristics of stress is beneficial to the comprehensive cognition to dynamic, which updated to the third party logistics legal relationship.

Finally, the main character of the third party logistics civil legal relation object is the essence of complexity. In theory, the third party logistics civil legal relation object connotation is more complex than the extension type, which is close to third party logistics civil legal relationship content, namely the rights and obligations of the legal relationship. The complexity of the legal 
relation object connotation in the third party logistics is derived from the theory of supply chain. The third party logistics activities can not only stay in the initial stage of the complexity of single chain, third party logistics has been strengthen by the aggravation of the market competition and the uncertainty of business.

\section{The contents of civil legal relationship in third party logistics based on the logistics contract}

The contents of logistics civil legal relationship between logistics service demander and provider, namely the rights and obligations between them, are reflected by the specific terms by the signed contract. The contract oriented customer service between the third party logistics enterprise and its customer enterprise cooperation relationship is more tightly, which is longer in time and makes the business alliance and enterprise strategic alliance becoming possible. Therefore, the third party logistics is often referred to as the "contract logistics" or "contract logistics". So the third party logistics civil legal relationship content was discussed from the perspective of contract logistics in this chapter.

Firstly, the nature and the law are applicable to the third party logistics contract. Outsourcing agreement is the basic form of the third party logistics contract, hybrid contracts atypical is the essential characteristic of third party logistics contract. The third party logistics is mainly composed of inbound and outbound logistics consisting of multiple service relationship, which lead to the application of logistics industry law presenting a mixed characteristics, complexity and levels of diversity. In different areas, there are corresponding legal norms to adjust the legal relationship of different species. At present, China has not established a specialized logistics method, steps and business logistics industry is mainly adjusted through a series of laws, administrative regulations, departmental rules, different aspects of the local logistics laws and regulations.

Secondly, the nature of third party logistics contract belongs to the bilateral contract, namely both sides must pay the payment obligation, and the rights of the party that are the other party's obligations. Among them, the logistics service involves the transport, storage, material handling and other links, so the contract rights and obligations will be shown the specific circumstances of the complex. The rights and obligations of the principal and the operation of logistics services logistics service people should be clearly, and to make clear of the collateral obligation.

Finally, the third party logistics liability for breach of contract should be taken pursuit of value as the imputation principle of basic. From the legislative technique, the law generally reflected as justice, security, efficiency, flexibility and other aspects of the pursuit of value. The third party logistics contract is a continuous, long-term, complex contract, the transaction process and performance is usually more complex, so the principle of determining liability the liability for breach of contract must be carefully weighed different value goal, with the parties to the transaction and to determine the position of interest.

\section{References}

[1] Mohan K.Menon, Michael A.McGinnis, Kenneth B. Ackerman. Selection Criteria for Pro viders of Third Party Logistics Service: An Exploratory Study. Journal of Business . 199 8.

[2] Douglas M.Lambert, Margaret A.Emmelhainz, John T. Gardner. Building Successful Logi stics Partnerships. Journal of Business . 1999

[3] Boysom,Corisim,Dresner,etc.Managing Effective Third Party Logistics Relationships: Wha t Does It Take?. Journal of Business . 1999.

[4] Wei Shi Lim. A Lemons Market An Incentive Scheme to Induce Truth-telling in Third Party Logistics Providers. European Journal of Operational Research. 2000.

[5] Henry Campbell Black.M.A. Black’s Law Dictionary. 2004. 